症例

\title{
甲状腺癌との鑑別に難渋した亜急性甲状腺炎の 2 例
}

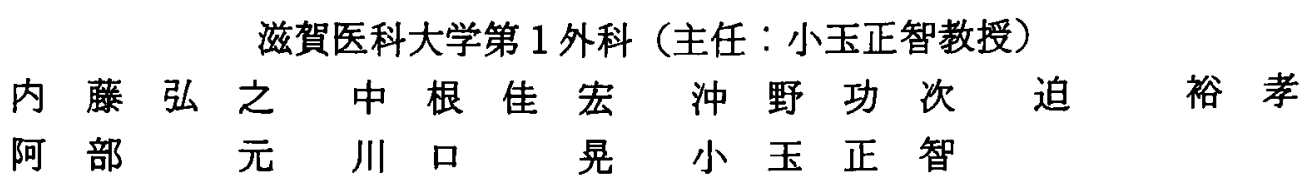

亜急性甲状腺炎の診断は，典型的な症状を呈する症例では容易であるが，甲状腺部の 压痛や急性炎症症状を欠く症例では，他の甲状腺疾患との鑑別に難沾する場合も少なく ない，最近，われわれは初診時，甲状腺部の王痛や急性炎症症状を欠くため，甲状腺癌 と診断した 2 例の要急性甲状腺炎を経験したので報告する。これらの症例は，いずれす 甲状腺に腫瘤を形成し，初診時の触診および超音波断層像からは，甲状腺癌と鑑別でき なかったが, 経過観察中に董瘤の変化を認め, 診断を確立しえたもので, その診断には, 畽瘤の触診所見および超音波断層像における経時的変化の追跡が有用であった。

索引用語：亜急性甲状腺炎, 甲状腺癌, 超音波断層像

\section{はじめに}

亜急性甲状腺炎は上気道炎に続発し，発熱，甲状腺 部の疼痛および压痛，CRP 陽性，血沈圥進，なぞの急 性炎症症状を呈し，しばしばー過性の甲状腺機能進 状態を示す族患で，30４0歳代の女性に好発し，ウィ ルスが原因とされている．典型的な症状を呈する場合 は，その診断は容易であるが，炎症症状を欠く場合に は，他の甲状腺疾患との鑑別に難沾する場合も少なく ない，最近，われわれは初診時，急性炎症症状を欠く ため，甲状腺癌と診断した 2 例の要急性甲状腺炎を経 験したので，若干の文献的考察を加え報告する。

\section{症例}

症例 $1: 35$ 歳，女性

主訴：前頸部腫瘤

既往歷：27歳時, 急性肝炎

家族歴：特記すべきことなし

現病歴：平成 2 年 3 月初旬, 前頸部腫瘤に気付き近 医を受診した。そその際，疼痛および上気道炎症状はな かった。超音波検查， CT 検査，甲状腺シンチグラ フィーを施行され，甲状腺癌の疑いのもとに，3 月30 日当科䊅介となった。

外来初診時現症：身長 $155.5 \mathrm{~cm}$, 体重 $46.0 \mathrm{~kg}$, 体温 36.5 度, 血王 $110 / 70 \mathrm{mmHg}$, 脈拍 70 回/分, 整であった。 胸腹部に異常を認めなかった。甲状腺峡部よりやや左

1990 年 7 月 30 日受付 1990 年 12 月 27 日採用
側に，大きさ $26 \times 18 \mathrm{~mm}$, 弾性硬, 辺縁不整, 可動性不 良で，圧痛を認めない腫瘤を触知した。

血洨生化学検查所見：血液生化学検查に異常値を認 めず，甲状腺機能も正常で，抗甲状腺抗体は陰性であっ た（表 1).

頍部軟線 X 線所見：石灰化および気管の変位像は 認められなかった。

顠部 CT 所見：甲状腺左葉に辺縁不整，内部不均一 な腫瘤陰影を認めた。

甲状腺シンチグラフィー所見：99mTc シンチクラ ムでは左葉全体に取り込みが減少していたが，201T1 シンチグラムには，集積像は認めなかった（図1）.

顠部超音波検査所見：甲状腺左葉に, 辺縁不整, 境 界不明瞭で，内部不均一な低エコー像を呈する腫瘤陰 影が存在した（図 2).

入院後経過：以上より，甲状腺シンチグラムの所見 は典型的ではないものの, 甲状腺癌を強く疑い, 手術 目的にて 4 月 6 日当科入院となった．ところが，入院 時所見で，左葉の腫瘤が著明に縮小しており，甲状腺 右葉全体に压痛があり，また37.4度の発熱が認められ たことにより，亜急性甲状腺炎が疑われた４月9日 には，左葉上極の $17 \times 15 \mathrm{~mm}$ 大の董瘤に加之，下極に $8 \times 8 \mathrm{~mm}$ 大の腫瘤も触知され，さらに右葉にも $32 \times 19$ $\mathrm{mm}$ 大の隀瘤が出現した. 38.4度の発熱があり, CRP $3.7 \mathrm{mg} / \mathrm{dl}$, 血沈 $34 / 90 \mathrm{~mm}$ と高値を示し，また, T3 3.03 $\mathrm{ng} / \mathrm{ml}, \mathrm{T} 417.1 \mu \mathrm{g} / \mathrm{dl}, \mathrm{TSH} 0.10 \mu \mathrm{IU} / \mathrm{ml}$ 以下と甲状 


\section{表 1 初診時現症および検査所見}

身長 $155.5 \mathrm{~cm}$ 体重 $46.6 \mathrm{~kg}$ 体温 36.5 度 血圧 $110 / 70$ 脈拍 $70 /$ 分

胸腹部に特記すべき所見なし

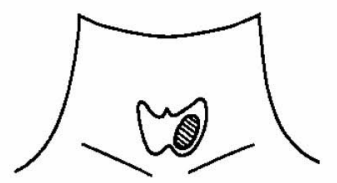

結節

$26 \times 18 \mathrm{~mm}$

弾性硬

辺縁不整

可動性不良

圧痛 $(-)$
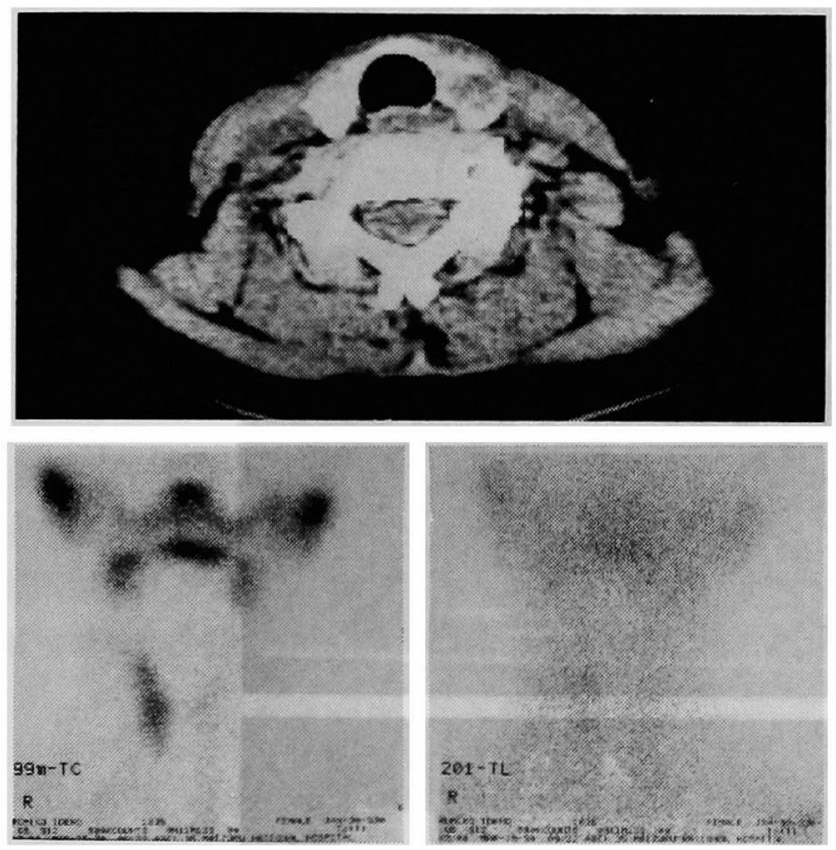

図 1 顠部 CT およひ状腺シンチグラム

腺機能も元進していた，以上より亚急性甲状腺炎と診 断した，治療は症状が軽度であったため，とくにステ ロイド斉は使用せず，消资鎮痛剂の投与で経過観察し たが，数日後には，前頸部痛は消失し腫瘤は縮小傾向 を示した。4月19日には，発熱も認められなくなり， $4.4 \mathrm{mg} / \mathrm{dl}$ ( 4 月12日) まで上昇した CRP も， $0.9 \mathrm{mg} /$ $\mathrm{dl}$ に，60/116mm(4月16日)までえ進した血沈も，40/ $85 \mathrm{~mm}$ と下降した。甲状腺機能は, T3 $3.79 \mathrm{ng} / \mathrm{ml}, 4$ $22.1 \mu \mathrm{g} / \mathrm{dl}$ と依然六進状態にあったが，臨床症状およ び血液検查上，改善傾向が認められたため，消炎鎮痛 剤の投与は，4 月20日で中止し，4 月22日には退院と なり，外来で経過観察することとなった。なお，吸引 細胞診は，4月 6 日と 4 月19日の 2 回施行し, 共に

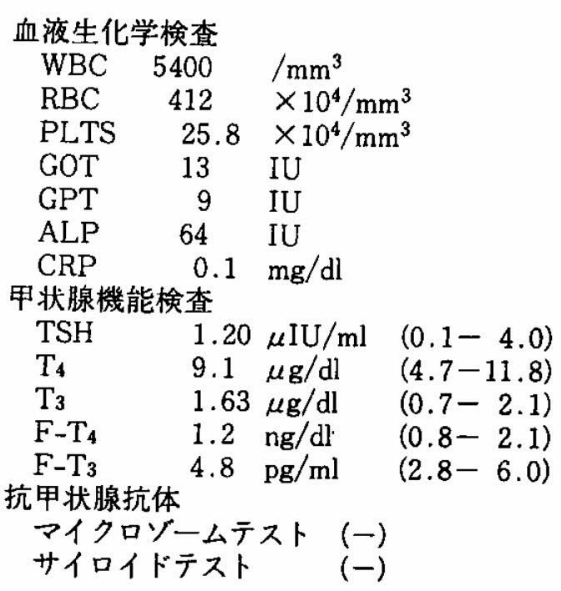

class 3であった。 また 5 月1日に施行した，123I シン チグラフィーでは, 撕取率は $0.09 \%$ と著明に低下して いた。

超音波断層像の経時的変化：甲状腺左葉の超音波断 層像に抢ける経時的変化を図 3 に示す. 初診時には 1 つであった腫瘤が，入院時には，上極および下極に 2 つ認められるようになり，それらが次第に縮小してい く経過が示されている。一方，右葉の超音波断層像の 経時的变化は図 4 のごとく，初診時には，はっきりし なかった腫瘤が, 入院後急速に増大し，4月13日をピー クとして 4 月21日には縮小傾向にある.

発症約 2 力月後の 5 月18日外来受診時の超音波検查 では，これらの腫瘤は完全に消失して打り，触診でも 全く触知されなかった，血液検査では，CRP $0.1 \mathrm{mg} /$ $\mathrm{dl}$, 血沈 $8 / 20 \mathrm{~mm}$ と正常化していた。一方, 甲状腺機能 は, T3 $0.85 \mathrm{ng} / \mathrm{ml}$, T4 $3.40 \mu \mathrm{g} / \mathrm{dl}$, TSH $35.9 \mu \mathrm{IU} /$ $\mathrm{ml}$ ，とむしろ機能低下となっていた（表 2).

さらに 2 力月後, 甲状腺機能は正常となっていた. 症例 $2: 38$ 歳, 女性

昭和62年11月, 検診で前頸部腫瘤を指摘され 11 月 27 日当科受診. 初診時, 左前頸部に $22 \times 18 \mathrm{~mm}$ の看瘤を 触知し, 超音波検査で甲状腺左葉に腫瘤を認めた。前 頸部の自発痛拉よび圧痛, 発熱, 上気道炎症状はなかっ た. CRP, 血沈, 甲状腺機能は正常であった。触診所 見招よび超音波検査上, 甲状腺癌が疑われ，12月17日 入院となった。ところが入院時, 腫瘤は縮小しており， 経過中 CRP は陽性となり, 血沈と甲状腺機能は元進 し, 亜急性甲状腺炎と診断した。約 2 力月後には, $\mathrm{CRP}$, 血沈, 甲状腺機能は正常となり, 触診および超 音波断層像において, 腫瘤は全く認めなくなった。本 症例は症例 1 と異なり, 全経過を通じて, 前頸部に自 

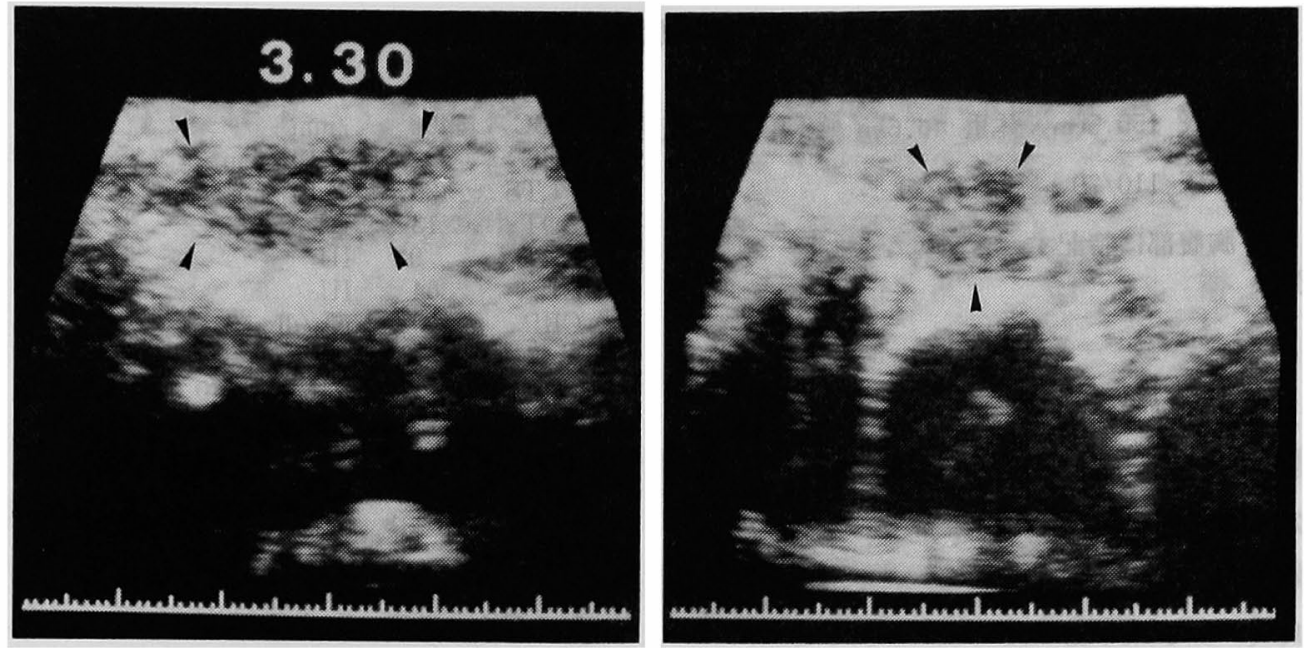

図 2 症例 1 における甲状腺超音波断層像（左：左葉長軸方向綐断像，右：横断像）
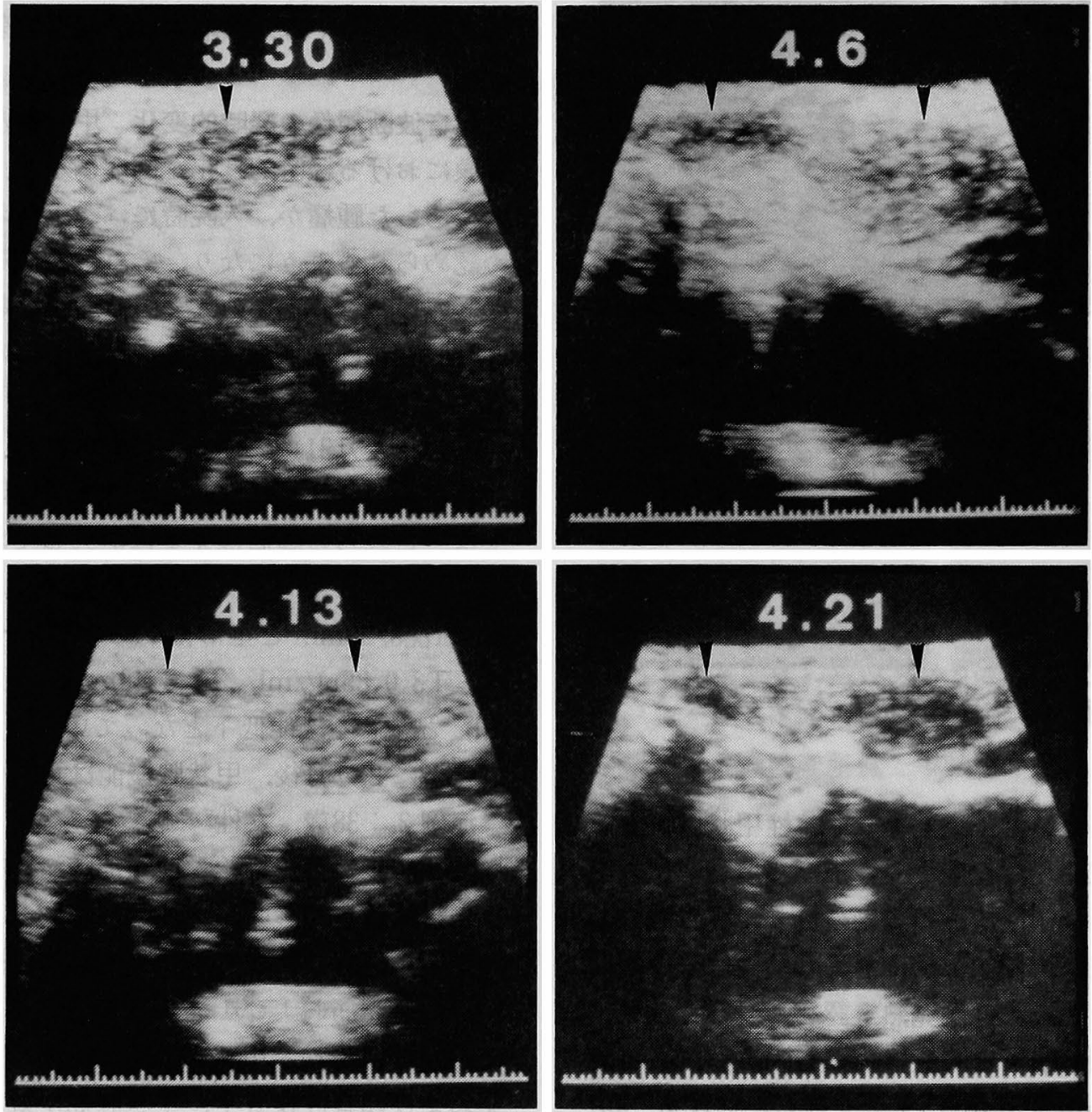

図 3 症例 1 の甲状腺超音波断層像（左葉長軸方向綎断像）に护ける時間経過

発痛, 王痛はなかった。初診時とその 3 週間後の超音 波断層像を図 5 に示す。11月27日に認められた，辺縁 不整, 内部不均一で低ェコーな腫瘤陰影は，12月17日 にはほとんど消失していた。
考察

亜急性甲状腺炎のなかには painless subacute thyroiditis と呼ばれる, 前頸部の王痛を伴わず, 一過 性の甲状腺機能六進状態を示す場合がある. Rotenber- 

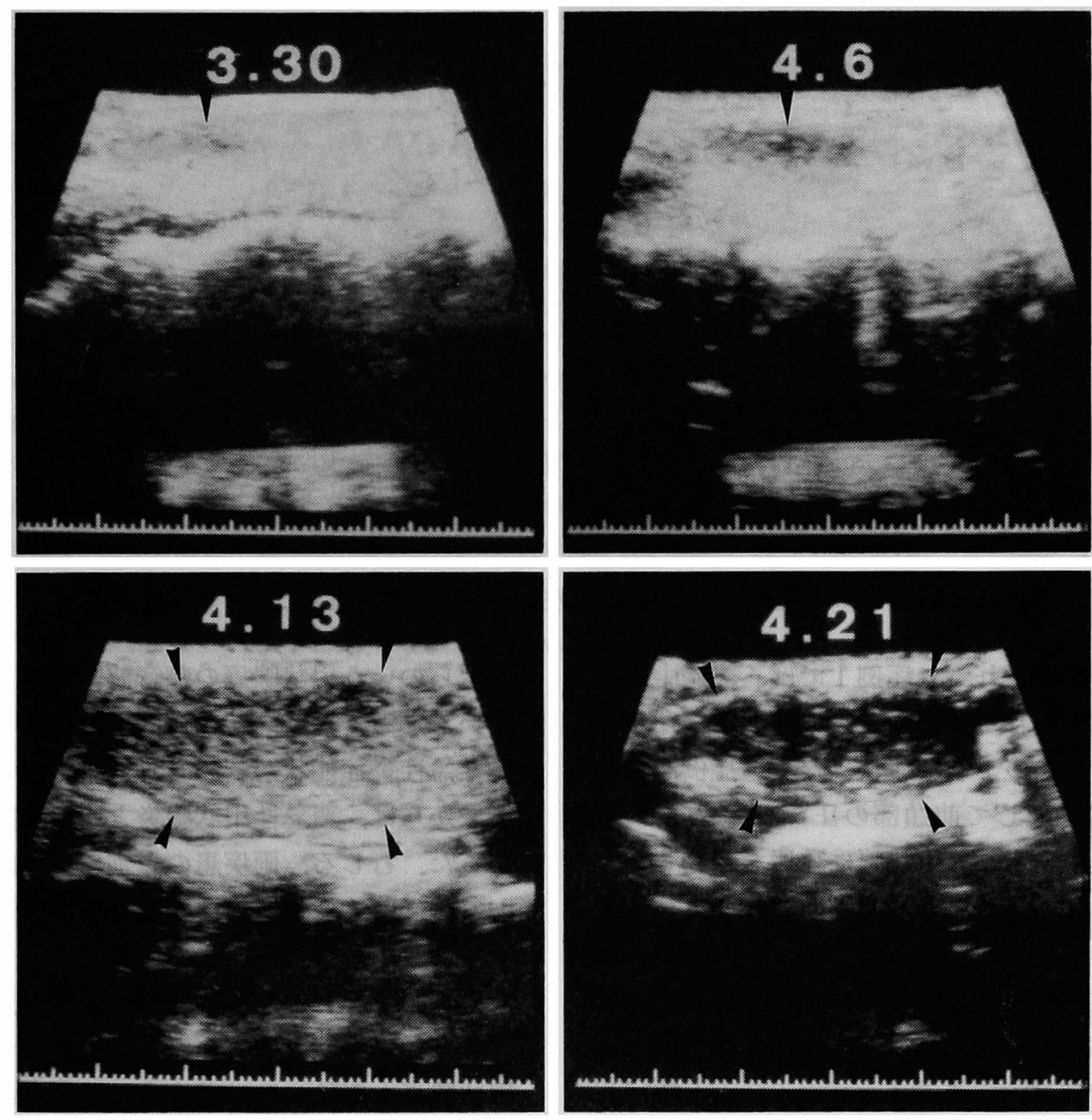

図 4 症例 1 の甲状腺超音波断層像（右葉長軸方向綎断像）に㧍ける時間経過

表 2 症例 1 の臨床経過

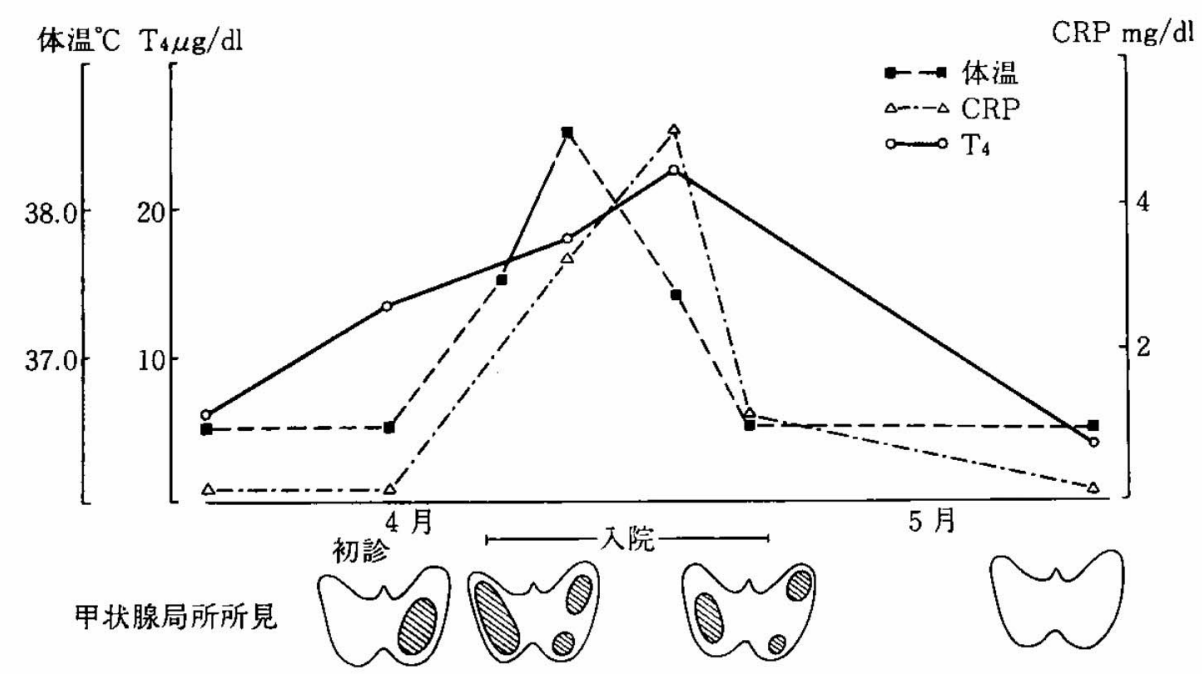

$\mathrm{g} 5^{1)}$ は, 35例の亜急性甲状腺炎のうち13例は前頸部の 圧痛を伴わない非典型的な亜急性甲状腺炎であったと し, Woolf $ら^{2)}$ は17例の亜急性甲状腺炎の 55 例は painless subacute thyroiditisであったと述べており， 決してまれではない。このような症例では，甲状腺機 能亢進症との鑑別や，腫瘤を形成する場合には，甲状 

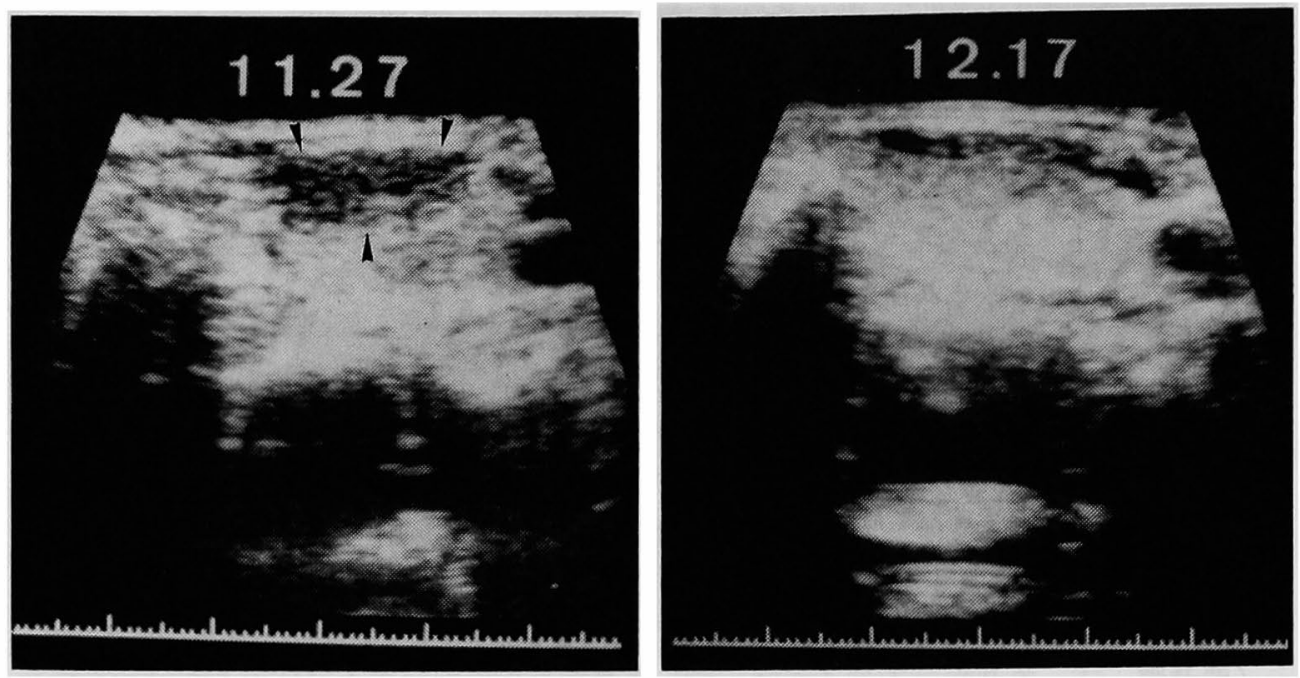

図 5 症例 2 の甲状腺超音波断層像（左葉長軸方向縦断像）における時間経過

腺癌との鑑別が要求される。症例 1 では，経過中に前 頸部の王痛が認められる様になり，典型的ではなかっ たが，初診時にはそのよらな症状はなく，症例 2 にお いては，全経過を通じて前頸部の圧痛は認められな かった、ゆえに，いずれも甲状腺に腫瘤を触知した今 回の 2 症例では，甲状腺癌との鑑別に難渋する結果と なった。

垔急性甲状腺资の超音波断層像についてはしばしば 報告されており, Miskin ら3の pseudo-cystic appearanceや, Blum'らの wash-out appearance と呼ばれ る著明な低エコ一像が特徵とされている。これらの報 告は $5 \mathrm{MHz}$ 以下の探触子によるものであったが, 長倉 $5^{5)}$ は, 7.5MHz の探触子による観察で, 本症の特徵的 所見として, 1.び漫型の董大あるいは曲玉形ないし不 整形を呈する限局型の腫大である.2. 内部エューの性 状は不均一なことが多く，またその内部ェューの反射 強度は低下する.3. 正常甲状腺組織との境界は不鮮明 である。の 3 点をあげており, 甲状腺癌との鑑別は比 較的容易であるとしている，今回報告した亜急性甲状 腺炎 2 症例はともに腫瘤を形成し, 超音波検查上, 辺 縁不整, 境界不明瞭, 内部不均一で低ェコー像を示し, 長倉らのいら亚急性甲状腺资の超音波断層像の特徽を 3 点とも有していたと言える. しかし，一方で，甲状 腺癌の超音波断層像に関して, 森藤ら ${ }^{61}$ は形態, 辺縁, 内部ェコー, 境界の 4 因子について検討し, 形態不整 扣よび辺縁不平滑な症例に甲状腺癌が多いとしてお り,また, 横沢ら”は, 甲状腺癌超音波診断基準造と辺 縁構造について検討し, 内部が不均一で低エコーを呈 する症例, 辺緣が不整な症例では, 甲状腺癌が多いと 述べている.われわれの 2 症例に拈いては, 森藤らゃ
横沢らのいら甲状腺癌の超音波断層像の特徴をむ呈し ていると考えられ，特に今回は亜急性甲状腺炎に典型 的な急性炎症症状が認められなかったため, 超音波断 層像からは，亜急性甲状腺炎と甲状腺癌は鑑別できな かった。むしろ, 両疾患の鑑別には, 超音波断層像に 扣ける経時的変化の追跡が最す有用であった。

$$
\text { まとめ }
$$

最近われわれは，甲状腺部の圧痛や急性炎症症状を 欠くため, 甲状腺癌との鑑別に難渋した 2 例の亜急性 甲状腺炎を経験した。両疾患の鑑別には腫瘤の触診所 見扣上び超音波断層像に打ける経時的変化の追跡が有 用であった。

\section{文献}

1) Rotenberg Z, Weinberger I, Fuchs J, et al: Euthyroid Atypical Subacute Thyroiditis Simulating Systemic or Malignant Disease Arch Intern Med 146: 105-107, 1986

2) Woolf PD, Daly R: Thyrotoxicosis with Painless Thyroiditis. Am J Med 60:73-79, 1976

3) Miskin M, Rosen IB, Walfish PG: B-Mode ultrasonography in assessment of thyroid gland lesions. Ann Intern Med 79:505-510, 1973

4) Blum M, Passalaqua AM, Sackler JP, et al: Thyroid echography of subacute thyroiditis. Radiology 125: 795-798, 1977

5）長倉穂積, 川内章裕, 原 秀雄他：亜急性甲状腺炎 の鑑別診断に扣ける超音波検查の有用性, 日超医 論文集 $48: 337-338,1986$.

6）森藤秀美, 吉中平次, 黒島一直他：超音波に打ける 結節性甲状腺腫の良・悪性の検討一形態・辺縁・内 部エコー・境界の 4 因子の各組織との相関一, 日外 会誌 $87: 564-571,1986$

7) 横沢 保：甲状腺癌の超音波診断に関する研究, 日外会誌 $89: 582-594,1988$ 


\title{
TWO CASES OF SUBACUTE THYROIDITIS DIFFICULT TO DISTINGUISH FROM THYROID CANCER
}

\author{
Hiroyuki NAITOH, Yoshihiro NAKANE, Kouji OKINO, Hirotaka SAKO, Hajime ABE,
} Akira KAWAGUCHI and Masashi KODAMA

First Department of Surgery, Shiga University of Medical Science

(Prof. Masashi KODAMA)

The diagnosis of subacute thyroiditis is not so difficult when it has typical symptoms. But in the case which has no tenderness of thyroid and no acute inflammatory symptoms, it is difficult to distinguish from another thyroid diseases. Recently we have encountered two cases of subacute thyroiditis. At first they were diagnosed as thyroid cancer because of lacking in typical symptoms. Both cases have a tumor in the thyroid, and we could not distinguish them from thyroid cancers by palpation and ultrasonographic findings. It was valuable to establish the diagnosis of subacute thyroiditis be following the changes in palpation and ultrasonographic findings of the tumors. 